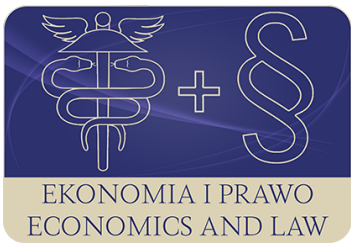

EKONOMIA I PRAWO. ECONOMICS AND LAW

Volume 17, Issue 2, June 2018

p-ISSN 1898-2255, e-ISSN 2392-1625

www.economicsandlaw.pl

ORIGINAL ARTICLE

received 13.06.2017; revised 23.03.2018; accepted 30.06.2018

Citation: Rzepka, A., \& Olak, A.J. (2018). Innovation as an immanent attribute of an agile enterprise.

Ekonomia i Prawo. Ecomomics and Law, 17(2): 211-221.

doi:10.12775/EiP.2018.015.

\title{
Innovation as an immanent attribute of an agile enterprise
}

\author{
AGNIESZKA RZEPKA \\ corresponding author \\ Lublin University of Technology, Faculty of Management, Department of Economics and Economic \\ Management, ul. Nadbystrzycka 38D, 20-618 Lublin, Poland \\ $\square$ a.rzepka@pollub.pl
}

ANDRZEJ J. OLAK

Bronisław Markiewicz State Higher School of Technology and Economics in Jarosław, Poland

曰aolak@onet.eu

\begin{abstract}
Motivation: Each organization faces the challenge of operating in an environment that is unpredictable and turbulent. Emergence of business era caused that change had become a key feature that determines the economic environment of an enterprise. Market environment forces companies to seek strategic orientation that would allow them to use market opportunities and come to grips with growing customer demands. These goals can only be achieved by an organization that bears the hallmarks of agility. Therefore, one can assume that the condition of gaining competitive advantage and innovation of modern companies is possessing by them the attributes of agility. The agile organization is innovative, which means that it puts an emphasis on research and development, implements innovation, invests in new technologies and innovative programs.

Aim: The purpose of this article is to analyse relationships between obtaining an ability

to be innovative and agility attributes of an organization.

Result: The presented research confirms that there is a connection between having agility attributes by a company and obtaining by it a high level of innovation. Many authors also specify important role of IT system in introducing product innovations and innovation processes.
\end{abstract}

Keywords: innovation; agile; SME

JEL: O30; M21; P42 


\section{Introduction}

The current economic reality makes the goal of each enterprise a wish to achieve success in the market. Enterprises of today operate in the extremely competitive environment of a global market. The increased rate of innovation and technological developments, fragmentation of markets and elevated customer expectations towards customized products lead to the especially turbulent and rapid changes in the business environment. The problem how organizations can successfully deal with an unpredictable and constantly changing environment has been a prevailing topic both in industry and academia for a few decades. Many different solutions were proposed: networking, reengineering, modular organizations, virtual corporations, high performing organizations, employee empowerment, flexible manufacturing, just-in-time production etc. No clues on how to survive in an unforeseen, turbulent business environment have been found yet.

One of the most widely discussed points and one of the most common proposals on how to deal with the aforementioned uncertain and unpredictable environment is the concept of agility. It was established as a response to new solutions, necessary for an enterprise to achieve success in a modern, rapidly changing market, in the field of production and company management. The goal of this article is to analyse the problem of a company innovation from the aspect of obtaining features of an agile enterprise.

This article, also lists the attributes of an agile organization and shows the dependencies between innovation and developing, by an enterprise, agility features.

\section{Literature review}

Agility is understood as the ability of an enterprise to react quickly and instantly adapt to new environment conditions in response to the continuous and unpredictable changes which happen on competitive markets. Rapid and at the same time successful response given by an enterprise involves the adjustment of all its components such as the technology, people, products, offer to unforeseeable transformations (Kidd, 1995, pp. 2-16).

Moreover, agility is defined as the ability of the company to prepare such offer that is flexible in nature and meets the sophisticated demands of individual customers. The agility, understood in such a way, means the ability to seize by a company new opportunities and treat them as necessary stimuli to set innovative market solutions that also take into account knowledge, inter-organizational relationships, human resources and their further use to obtain competitive advantage (D’Aveni, 1994, pp. 1-14).

The concept of agility initially developed in the domain of production. However, it was noted that its assumptions may relate to other functions of the company what, as a result, led to the creation of the term of 'agile enterprise' 
(Goldman et al., 1991, pp. 3-18). Currently, a number of views on how to understand this concept exist. Some of them are related to just one specific feature of an organization, other present a broad view meaning of agility, some seek to establish, on the one hand, relationships between the dimensions of agility (Goldman et al., 1995, pp. 34-42) and related attributes, and, on the other hand, business performance and competitive bases of an organization. Agility (Narasimhan et al., 2006, pp. 577-603) has been explored in a number of studies and seen as a system with exceptional internal capabilities including hard and soft technologies, human resources, educated and highly motivated management, and information and communication technologies that as a whole meet the rapidly changing needs of the market place with speed and flexibility.

According to S. Trzcieliński (2011, p. 97), 'agility' should be treated in the category of the new paradigm of an enterprise. The author suggests that this concept is not a particular state or one, single condition, it may reach different levels. S. Trzcieliński's model of agile enterprise describes an agile enterprise in four dimensions: shrewdness, resource flexibility, enterprise's intelligence, and smartness of the enterprise. These agile dimensions are interpreted from the situational conditions of an enterprise: internal and external factors. The internal factors are: market orientation, product / service customization, key process creating market advantage, business goals, and organizational goals. The external factors are levels of branch stability (Pawłowski, 2015, p. 3). The author suggests that only on the 'zero level', the agility may be treated as a concept ascribed to lean enterprise limiting itself only to methods that constitute a common part of both metaconceptions. These dependencies were presented in scheme 1 .

Agility is also referred to agile manufacturing as assimilation of all flexible production technologies, together with experience gained from total quality management (TQM), 'just-in-time' production (JIT), and lean production.

Another interpretation of the concept of agility is more narrow and one side oriented. According to it, the main emphasis is placed on the ability of rapid adaptation. An agile enterprise is able to skilfully and quickly react to market changes (Kidd, 1995, pp. 2-16). What is more, an agile organization has the ability to identify market needs and potentials promptly, see the strengths and opportunities of the company, and if it is necessary, to revaluate or redefine the mission, vision and values of the organization. At this phase, the market focus approach initiates its construction through the generation of procedures, rules and politics that guarantee a real market focus orientation along the organization. Such focus allows the organization also to react to crisis situations well (Kumar \& Motowani, 1995, pp. 36-53).

\section{Methods}

The problem — agility and innovation — was analyzed on the basis of empirical research of an international character. The points out that adopting by a com- 
pany agility attributes translates into a better competitive position and a higher level of innovation. Innovation in an enterprise constitute an impulse to take new challenges, which perfectly fits into the paradigm of the organization's agility. In turn, through innovation, companies become agile.

\section{Attributes of agile organization}

The attributes of an agile organization include: speed and flexibility and effective response to change and uncertainty (McGaughey, 1999, pp. 7-13). Agility is based on several capabilities found in three main enterprise dimensions: manufacturing, product, and market. Jackson and Johansson (2003, pp. 482-488) divided agility capabilities into four main dimensions: product-related change capabilities, change competency within operations, internal and external co-operation, and people, knowledge, and creativity. Owing to this, the whole organization is able to survive in unpredictable market conditions by giving an appropriate response to turbulence in business environment (Rigby, 2000, p. 74). By making an efficient shift on operational level, the organization fulfils the responsibility of the day-to-day operations that directly affect a company's external customers. This makes the operational level crucial to the success of the strategic and competitive goals of an organization which adapts dynamically itself to demands and requirements of the external environment (Narasimhan et al., 2006, pp. 577-603).

If the organization is responding to a threat through delivery of existing flexible responses it is conceivable that the time to deliver a response would be different from the time to deliver a response if the organization has to rely on learning and adaptation to deliver options that enhance its flexibility and therefore enable delivery of a new effect. It is conceivable that an organization that has the necessary acuity can successfully anticipate or be aware of possible threats and therefore may recognize that it does not have the manifest agility to respond to a threat but it may have sufficient warning to enhance its flexibility prior to any threat being realized. Similarly, a response to anticipating threats may be to lake proactive action to affect the environment; that is, risk mitigation activities.

A conceptual model of agility lies within an organization encompassing also the design and learning space. Essentially, one aspect of agility within this model sees the organization as being within a sense-and-respond loop, only breaking out of the loop when not able to offer an appropriate action to a manifest or possible threat. Experimentation, discovery and innovation would form part of the productivity input drawing on appropriate resources, skills and capabilities and considering capability size and depth. Learning takes place within the system design and learning space with reactive and proactive responses feeding into a continual learning activity challenging the organization to consider impacts on the resilience space. 
B. Pichlak (2012, p. 67) points to the fact that currently organizations had to develop such capabilities and skills that would enable them to operate and function in permanently unstable market conditions. Abilities that bring profits, in an environment in which in a conscious and unpredictable manner the possibilities to satisfy customer needs change, are defined as agility. As part of these capabilities the most important is their strategic dimension, defined as strategic agility or strategic responsiveness, but no less important is also the ability of a flexible and efficient operation on the operational level strictly related to operational agility or organizational flexibility.

The author also differentiates attributes of an agile enterprise which has a desire to implement innovation. They include: the tendency to generate innovation, ability to implement innovation, willingness to take risk.

Agility is, therefore perceived as an ability to survive despite the threats existing in business environment. An agile enterprise is able to gain a competitive advantage whenever it has the opportunity to do so (Zhang \& Sharifi, 2000, pp. 496-513).

There are also other definitions which treat the organisational agility as a spectre of features related to production, marketing, experience, innovation, management, strategy and many more layers of an organization (Storey et al., 2005, pp. 242-260). Generally, an agile enterprise is able to get satisfaction of customers and own employees (Dahmardeh \& Banihashemi, 2010, pp. 9-14) owing to the use of such features as: flexibility, acuity, intelligence and smartness (Trzcieliński, 2011, p. 97).

It may be stated that in contemporary economic reality only a company bearing the attributes of agility is able to survive. These attributes were specified in scheme 2. Generally, agility of an enterprise consists of inter-related dimensions. For example, product related capabilities of enterprise to deal with uncertain and dynamic business environment. Cooperation related agility is connected with the extent that an organization can cooperate internally and externally with other companies, customers and suppliers. Organization related agility enables the enterprise to utilize all existing resources regardless of their location in order to provide a product to the market as rapidly and cost effectively as possible. People and knowledge related agility allows a rapid reconfiguration of the human and physical resources in the response to changes in the market. Manufacturing agility dimension is related to the competencies, methods and tools used to manage the short term and long term changes within production system and so on (Sherehiy, 2007, pp. 445-460)

It is worth to notice that all of the aforementioned attributes and capabilities of an enterprise are strictly related to the concept of innovation. An agile enterprise, as it was said before, is able to respond quickly to new opportunities, market shifts, threats and crisis situations making progress from even unfavourable business conditions. None of it would be possible without the application of better solutions, that meet new requirements, based on effective products, 
processes, services, technologies, and human resources management, known as innovation.

\section{Innovation vs agile enterprise}

Innovation can be understood as a process of learning and knowledge creation through which new problems are defined and new knowledge is developed to solve them. It is a process by which these ideas are captured, filtered, funded, developed, modified, clarified, and eventually commercialized and/or implemented. Simply put, innovation is about the creation and implementation of a new idea with the purpose of delivering commercial benefits. Innovation may be classified according to the nature of the change it brings into effect. Innovation is driven by employees' resources: ideas, creativity, competence and problem-solving abilities and by the technological resources of a company (Lasrado et al., 2015, pp. 182-210).

Developing an ability to give an effective response to forthcoming changes in business environment requires innovative measures that lead to obtaining the highest effectiveness, efficiency and customers satisfaction. Quick response to stimuli coming from the environment, flexibility in operation and competence can be achieved by applying innovative practices and tools as the latest management technique. Undoubtedly, the ability of an organization to 'produce novelties' - in the field of products, services or business processes may become an integral feature of an agile enterprise that is able to thrive in an increasingly volatile world.

The management of challenges in contemporary business makes high requirements to people, groups of people, social groups as well as nations and civilizations. One way to meet these challenges is to find a niche that is based on creating unique products, goods or services what, in turn, requires implementing innovative processes (Olesiński et al., 2016, pp. 31-33).

Innovative processes are shaped by the information coming from the market. Agile enterprises use these information, serve them as an impulse to act and as a challenge to implement new goals. The ability of making a diagnosis and categorizing necessary resources that are useful in identifying market opportunities, evaluating the adequacy of own resources and obtaining necessary resources from the environment constitutes a basis for determining innovative needs (Sajdak, 2013, p. 73).

\section{Results}

The interest in finding connection between agility and innovation has been examined in various contexts. Researches took place in the form of theoretical analysis of various dimensions of organizations functioning. The outcome proves that there is a close connection between agility and innovation and that 
the attributes of agility contribute to the innovative capacity of an organization (Rzepka, 2017, p. 163).

Zain et at. (2005, pp. 829-839) have studied the fact whether the acceptance and acquisition of new technologies have a positive impact on organizational agility. The technology acceptance model proposed in this study confirmed the hypothesis that the attitude towards new IT solutions affects organizational agility through the actual use of IT solutions in the enterprise. The attitude towards the new IT system is a function of perceived usability and ease of use. The results confirmed the hypothesis that the perceived usability and ease of use of the system affect organizational agility through the actual use of the IT system and the attitude towards technology. The survey showed that out of six external variables (user involvement, work and system characteristics, user experience, support of senior management and demographic characteristics) only two variables (work and system characteristics) have a significant impact on agility.

The table 1 presents a list of research connected with the influence of the agility of an organization on innovation. The researches presented in the table 1 confirm that there is a close connection between forming by a company agility features and obtaining by it a high level of innovation. Introducing innovation gives an impulse for undertaking new challenges what perfectly fits in with the paradigm of the company's agility.

\section{Conclusion}

Unpredictability and volatility of the business environment causes that the competitive position of enterprises is not permanent. Sources of competitive advantage of an individual enterprise are subject to constant turbulences. Therefore, the organization must constantly look for ways to survive and achieve success. In order to do this, it must develop the agility features. Attributes of agility certainly include:

- speed and flexibility;

- the response to change and uncertainty;

- high quality and highly personalized products;

- products and services with a high information content and added value;

- launching key competences;

- reaction to social and environmental problems;

- synthesis of different technologies;

- integration both in and outside the company and between companies.

Only an organization that bears such features has a chance to succeed and innovate. Indeed, the studies listed in this article, and their outcome prove that agility and innovation intertwine and that the attributes of agility translate into achieving by an enterprise a better competitive position and higher level of innovation. 


\section{References}

Dahmardeh, N., \& Banihashemi, S.A. (2010). Organizational agility and agile manufacturing. European Journal of Economics, Finance and Administrative Science, 27.

D'Aveni, R.A. (1994). Hypercompetition: managing the dynamics of strategic manoeuvring. New York: Free Press.

Goldman, S.L., Preiss, K., Nagel, R.N., \& Dove, R. (1991). 21st century manufacturing enterprise strategy: an Industry-Led View. Bethlehem: Iacocca Institute at Lehigh University.

Goldman, S.L, Nagel, R.N, \& Preiss, K. (1995). Agile competitors and virtual organizations: strategies for enriching the customer. New York: Van Nostrand Reinhold.

Jackson, M., \& Johansson, C. (2003). An agility analysis from a production system perspective. Integrated Manufacturing Systems, 14(6). doi:10.1108/09576060310491342.

Kidd, P.T. (1995). Agile manufacturing: a strategy for the 21st Century. doi:10.1049/ ic:19960497.

Kumar, A., \& Motowani, J.A. (1995). A methodology for assessing time-based competitive advantage of manufacturing firms. International Journal of Operations and Production management, 15(2). doi:10.1108/01443579510080409.

Lasrado F., Arif, M., \& Rizvi, A. (2015). The determinants for sustainability of an employee suggestion system. International Journal of Quality \& Reliability Management, 32(2). doi:10.1108/IJQRM-02-2013-0035.

McGaughey, R.E. (1999). Internet technology: contributing to agility in the twenty-first century. International Journal of Agile Management Systems, 1(1). doi:10.1108/14654659910266655.

Narasimhan, R., Talluri, S., \& Mahapatra, S.K. (2006). Multiproduct, multicriteria model for supplier selection with product life-cycle considerations. Decision Sciences, 37(4). doi:10.1111/j.1540-5414.2006.00139.x.

Olesiński, Z., Rzepka, A., \& Sabat, A. (2016). Międzyorganizacyjne sieci wspótpracy gospodarczej na przyktadzie Polski, Kanady i Gruzji. Warszawa: Texter.

Pawłowski, K. (2015). Operationalization of supply chain agility in an enterprise operating in high market orientation. Gospodarka Materiatowa i Logistyka, 12(3).

Pichlak, M. (2012). Uwarunkowania innowacyjności organizacji. Studium teoretyczne i wyniki badań. Warszawa: Difin.

Rigby, K. (2000). Bullying in schools: guidelines to effective action. Professional Reading Guide for Educational Administrators, 21(1).

Rzepka, A. (2017). Inter-organizational relations as a one of sources of competitive advantage of contemporary enterprises in the era of globalization. Procedia Engineering, 174. doi:10.1016/j.proeng.2017.01.195. 
Sherehiy, B., Karwowski, W., \& Layer, J.K. (2007). A review of enterprise agility: concepts, framework and attributes. International Journal of Industrial Ergonomics, 37(5). doi:10.1016/j.ergon.2007.01.007.

Sajdak, M. (2013). Innowacyjność jako niezbędna cecha zwinnego przedsiębiorstwa. Wrocław: UE we Wrocławiu.

Sharifi, H., \& Zhang, Z. (1999). A methodology for achieving agility in manufacturing organisations: an introduction. International Journal of Production Economics, 62(1-2). doi:10.1016/S0925-5273(98)00217-5.

Storey, J., Emberson, C., \& Reade, D. (2005). The barriers to customer responsive supply chain management. International Journal of Operations \& Production Management, 25(3). doi:10.1108/01443570510581853.

Trzcieliński, S. (2011). Przedsiębiorstwo zwinne. Poznań: Politechnika Poznańska.

Zain, M., CheRose, R., Abdullah, I., \& Masromd, M. (2005). The relationship between information technology acceptance and organizational agility in Malaysia. Information and Management, 42(6). doi:10.1016/j.im.2004.09.001.

Zhang, Z., \& Sharifi, H. (2000). A methodology for achieving agility in manufacturing organizations. International Journal of Operations \& Production Management, 20(4). doi:10.1108/01443570010314818.

\section{Acknowledgements}

Author contributions: authors have given an approval to the final version of the article. Authors contributed to this work as follows: A.R. developed the concept and designed the study, A.J.O. collected the data, A.R. analysed and interpreted the data, A.R. prepared draft of article, A.R. \& A.J.O. revised the article critically for important intellectual content.

Funding: this research was fully funded by the authors.

Note: the results of this study were presented at 9th International Conference on Applied Economics Contemporary Issues in Economy (June 22-23, Toruń, Poland). 


\section{Appendix}

\section{Table 1.}

\section{The list of research made on the influence of the agility of an organization on innovation}

\begin{tabular}{ll}
\hline \multicolumn{1}{c}{ Researcher } & \multicolumn{1}{c}{ The result of research } \\
\hline $\begin{array}{l}\text { V. Sambamurthy, } \\
\text { A. Bharadwaj, }\end{array}$ - & indicating a significant impact of investments made in innovation; \\
V. Grover & -
\end{tabular}

Source: Own preparation based on Sajdak (2013, p. 73).

\section{Scheme 1 .}

Leanness of an enterprise as a condition for its agility

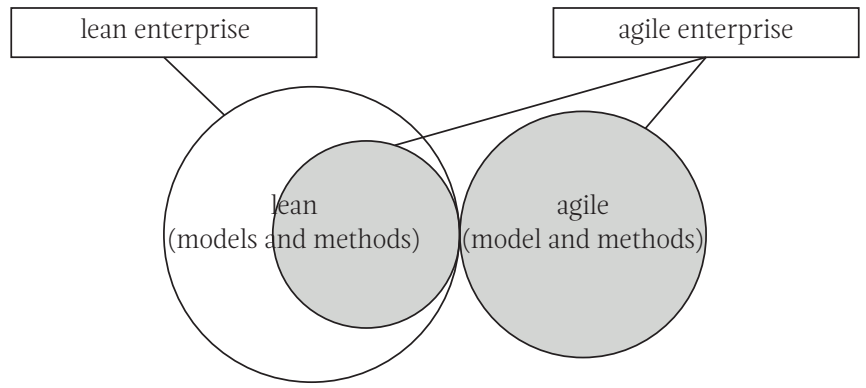

Source: Trzcieliński (2011, p. 97). 


\section{Scheme 2.}

\section{Attributes of an agile enterprise}

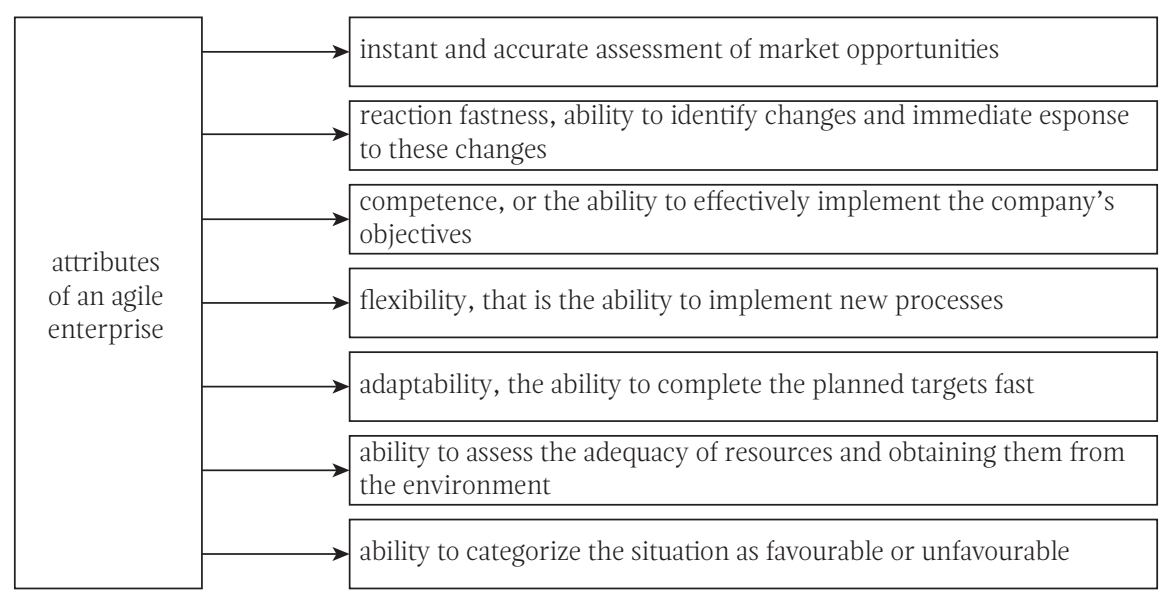

Source: Own preparation based on Sharifi and Zhang (1999, pp. 7-22). 
